\title{
QUALITATIVE DETECTION OF ANTIBIOTIC RESIDUES IN BROILER MEAT OF LOCAL POULTRY FARMS IN SLEMANI
}

\author{
NAZAR ALI AMEEN ${ }^{1}$, EMAN DHAHIR $^{2}$, DERIN UMER ${ }^{3}$ and HERO HUSSAIN RAUF ${ }^{4}$ \\ ${ }^{1}$ Department of Histopathology. (nzarameen@yahoo.com). \\ ${ }^{2}$ Department of Microbiology (emandhahir@yahoo.com). \\ ${ }^{3}$ Department of Basic Science (dereen73@ yahoo.com), College of Veterinary Medicine, Sulaimania University. \\ ${ }^{4}$ Sulaimania Veterinary Directorate, (i.sulaimaneyah@yahoo.com).
}

Received: 21 March 2019; Accepted: 1 April 2019

\begin{abstract}
Due to their availability and low cost, antibiotics have been widely used in the broiler farms in sulaimani province specially and in Iraq generally. A total of 107 samples have been collected from August 2013 till June 2014 and the samples were breast, thigh muscles liver and kidneys. The samples analysed qualitatively by microbiological inhibition method for possibility of presence of antibiotic residues, the results appeared that there were no antibiotic residues in the samples of breast and thigh muscles while there were three samples positive for each of liver and kidney samples these levels are lower than those established.
\end{abstract}

Key words: Antibiotic, Residue, Microbiological inhibition test. Broiler meat

\section{INTRODUCTION}

The presence of antibiotic residues in the foodstuffs of animal origin is one of the most important indexes for their safety.

The use of antimicrobials for the treatment or prevention of disease in animals closely followed their uses in humans (Gustafson and Bowen, 1997) and today antimicrobial drugs are used to control, prevent and treat infection, and to enhance animal growth and feed efficiency (Tollefson and Miller, 2000).

Currently, approximately $80 \%$ of all food-producing animals receive medication for part or most their lives (Lee et al., 2001).

This use of antibiotic drugs in food-producing animals may result in the presence of residues in meatland offal. Protection of public health against possible harmful effects of veterinary drug residues is a very important problem, furthermore, there has been an increasing international and local awareness of the danger of consuming food products with drug residues. Many of them are now classified as carcinogenic, toxic and allergenic (Mahgoub et al.,

Corresponding author: Dr. NAZAR ALI AMEEN

E-mail address: nzarameen@ yahoo.com

Present address: Department of Histopathology.
2006). Growing concern among consumers and public health authorities regarding the presence of antibiotic residues in animal origin foods demands better control in the use of antimicrobials in animal production (Popelka et al., 2005). The presence of antibiotic residues, which are used on a large scale in poultry farming, in chicken muscle and in liver samples has been demonstrated by some previously published data (de Wasch et al., 1998; Tajick and Shohreh 2006; Miranda et al., 2009; Tajik et al., 2010).

A wide range of antibiotics are used in poultry not only to treat disease but also to maintain health, promote growth and enhance feed efficiency (Gaudin et al., 2004). Antibiotic usage has facilitated the efficient production of poultry, allowing the consumer to purchase, at a reasonable cost, high quality meat and eggs (Donoghue, 2003).

In particular, broiler chickens are often grown actively with antibiotics to attain maximum weight within a short period of time (Nonga et al., 2009).

Nutritional and health value of chicken meat have recently been perceived by consumers and demand has increased considerably in Kurdistan region, therefore, the aim of this research is the possibility of presence of antibiotic residues in broiler meats in local farms (at marketing time) and fresh meats present in the markets of Sulaimaniya province. 


\section{MATERIALS AND METHODS}

From August 2013 to June 2014, a total of 107 raw and ready to eat samples were collected in Sulaimania province, Iraq, and transported to the laboratory immediately after sampling, each sample consisting of breast muscles, thigh muscles, liver and kidney.

Bacterial suspensions Bacillus subtilis, Mueller Hinton agar (Oxoid, CM 337), Autoclave, Sterile Petri plates (diameter $90 \mathrm{~mm}$ ), Incubator have been used in present research.

The test procedure is as follows: using Bacillus subtilis as the test organism, a $0.5 \%$ McFarland's standard suspension of the organism was prepared. This was used to inoculate the surface of MuellerHinton agar plates prepared at $\mathrm{pH} 7.0$ and containing $0.2 \mathrm{mg} / \mathrm{ml}$ of trimethoprim. A sterile $8 \mathrm{~mm}$ diameter cork borer was used to create disc shaped samples of $2 \mathrm{~mm}$ thickness, which were applied to the surface of the agar medium. Positive controls were set up with $1 \mathrm{mg} / \mathrm{ml}$ of ciprofloxacin, chloramphenicol and tetracycline, while negative controls were set up with distilled water. The agar plates were incubated at $37^{\circ} \mathrm{C}$ for $24 \mathrm{~h}$. After incubation a zone of inhibition of $1 \mathrm{~cm}$ or more was considered a positive case of the samples containing drug residues. (Koenen-Dierick et al., 1995), (Babapour et al., 2012).

\section{RESULTS}

Table (1): Number and incidence of antibiotic residues in muscles, liver and kidney samples

\begin{tabular}{|c|c|c|c|c|c|}
\hline \multirow[t]{2}{*}{ Type of samples } & \multirow{2}{*}{$\begin{array}{c}\text { Number of } \\
\text { samples }\end{array}$} & \multicolumn{2}{|c|}{ Positive } & \multicolumn{2}{|c|}{ negative } \\
\hline & & No. & $\%$ & No. & $\%$ \\
\hline Liver & 107 & 3 & 2.8 & 104 & 97.1 \\
\hline Kidney & 107 & 3 & 2.8 & 104 & 97.1 \\
\hline Breast muscle & 107 & 0 & 0 & 107 & 100 \\
\hline Total & 321 & 6 & 1.86 & 315 & 98.13 \\
\hline
\end{tabular}

\section{DISCUSSION}

The results for the samples contain some residues of antibiotics even though these levels are lower than those established by the European Union, their presence may still be regarded as a health hazard for consumers since they may cause allergic reactions or contribute to the generation of antibiotic-resistant strains of bacteria which became a worldwide problem in the treatment of human infectious diseases. For this reason, ministry of agriculture and veterinary directorates have to set up strict monitoring plans for controlling veterinary drug residues in poultry and their products.

A total of 321 samples were taken randomly and investigated for detection of antibiotics residues, table 1 shows the results from analyzing of the samples from meat (breast muscles), liver and kidneys of broiler chickens, the result of these investigations was that there were no samples from breast muscle identified as antibiotic-residuepositive while Liver and kidney samples showed positive results of 3 samples of each $(2.8 \%)$, this result revealed the low incidence of antibiotic residues in the samples.
The results of present investigation is in accordance to the results showed by (Pavlov et al., 2008), whom showed that a total of 15,45 and 35 breast meat, liver and kidney samples respectively; there were no antibiotic residues in breast meat samples while liver and kidney samples had 2 and 4 positive antibiotic residue samples respectively, also the recent results dislike to the results appeared by (Shareef et al., 2009) and (Gebre, 2013) whom showed high incidence of antibiotic residues in their samples.

The interpretation of these results of low incidence of antibiotic residues in the samples is attributed to a consideration of withdrawal time of drugs by the farmer because all farms fortunately, are under strict monitoring by ministry of agriculture representative by general veterinary directorate and veterinary directorates in Slemani region; the rule is that each farm has its own veterinarian supervisor.

\section{RECOMMENDATIONS}

The use of antibiotics for growth promotion in animals should be terminated if it is used in human therapeutics and known to select for cross resistance to antimicrobials used in human medicines. In 
Kurdistan region there is no system for detection of antibiotic residues in animal foods. There are some studies on detection of antibiotic residues in poultry meat, eggs and milk by Spectrophotometry. But this procedure is lengthy, laborious and costly as compared to microbiological inhibition assay. So therefore present study was carried out to know how much does it applicable an antibiotic residue detection test by using local Bacillus subtilis strain as a test organism.

\section{ACKNOWLEDGMENT}

The authors thank the College of Veterinary Medicine, University of Sulaimani, for providing all supports for this experiment.

\section{REFERENCES}

Donoghue, D.J. (2003): Antibiotic residues in poultry tissues and eggs: Human health concerns: Poultry Science, 82: 618-621.

Gaudin, V.; Maris, P.; Fusetier, R.; Ribouchon, C., Cadieu, N. and Rault, A. (2004): Validation of a microbiological method: The Star protocol, a five plate test for screening of antibiotic residues in milk. Food Additives and Contaminants 21: 422-433.

Gustafson, R.H. and Bowen, R.E. (1997): Antibiotic use in animal agriculture. J. Appl. Microbiol., 83, 531-541.

Lee, H.J.; Lee, M.H. and Ruy, P.D. (2001): Public health risks: chemical and antibiotic residues. Asian-Aust. J. Anim. Sci. 14, 402-413.

Nonga, E.; Mariki, M.; Karimuribo, D. and Mdegela, H. (2009): Assessment of antimicrobial usage and antimicrobial residues in broiler chickens in Morogoro Municipality, Tanzania. Pakistan Journal of Nutrition 8: 203-207.

Tollefson, L. and Miller, M.A. (2000): Antibiotic use in food animals: controlling the human health impact. J. AOAC. Int., 83, 245-256.

Koenen-Dierick, L.; Okerman, L.; De Zutter, L.; Degroodt, J.M.; Hoof, J.V. and Srebrnik, S.A. (1995): One-plate microbiological screening testing in kidney tissue and meat; an alternative to the EEC four plate method? Food Additives and Contaminants, 12(1): 77-82.

Babapour, A.; Azami, L. and Fartashmehr, J. (2012): Overview of Antibiotic Residues in
Beef and Mutton in Ardebil, North West of Iran, World Applied Sciences Journal 19 (10): 1417-1422.

Mahgoub, O.; Kadim, IT.; Mothershaw, A.; Al Zasjali, SA. and Annamalai, K. (2006): Use of enzyme linked immunosorbent assay (ELISA) for detection of antibiotic and anabolic residues in goat and sheep meat. World J Agric Sci. 2:298-302.

Popelka, P.; Nagy, J.; Germuska, R.; Marcincak, S.; Jevinova, $P$. and de Rijk, A. (2005): Comparison of various assays used fordetection of beta-lactam antibiotics in poultry meat. Food Addit Contam. 22: 557562.

Miranda, JM.; Rodri'guez, JA. and Gala'n-Vidal, CA. (2009): Simultaneous determination of tetracyclines in poultry muscle by capillary zone electrophoresis. J Chromatogr A 1216: 3366-3371.

De Wasch, K.; Okerman, L.; Croubels, S.; de Brabander, H.; Hoof, JV. and de Backer, P. (1998): Detection of residues of tetracycline antibiotics in pork and chicken meat: correlation between results of screening and confirmatory tests. Analyst 123: 2737-2741.

Tajick, MA. and Shohreh, B. (2006): Detection of antibiotics residue in chicken meat using TLC. Int J Poultry Sci. 5:611-612.

Tajik, H.; Malekinejad, H.; Razavi-Rouhani, SM.; Pajouhi, MR.; Mahmoudi, R. and Haghnazari, A. (2010): Chloramphenicol residues in chicken liver, kidney and muscle: a comparison among the antibacterial residues monitoring methods of four plate test, ELISA and HPLC. Food Chem Toxicol. 48:2454-2468.

Pavlov, A.L.; Lashev, L.; Vachin, I. and Rusev, V. (2008): RESIDUES OF ANTIMICROBIAL DRUGS IN CHICKEN MEAT AND OFFALS, cTrakia Journal of Sciences, Vol. 6, Suppl. 1, pp 23-25.

Gebre, B.A. (2013): Qualitative screening of antibiotic residues and identification of antibiotic resistant salmonella from raw and ready to eat meat in Thailand, International Journal of Advanced Life Sciences, Volume (5) Issue (1) November.

Shareef, A.M.; Jamel, Z.T. and Yonis, K.M. (2009): Detection of antibiotic residues in stored poultry products, Iraqi Journal of Veterinary Sciences, Vol. 23, Supplement I, pp (45-48). 


\section{التحري النوعي عن بقايا المضادات الحياتية في لحوم فروج اللحم في قاعات محافظة السليمانية}

\section{' نزار علي /مين ، ' ايمان طاهر عارف ، " ديرين عدر محمد رمي ، " هيرو حسين رؤوف}

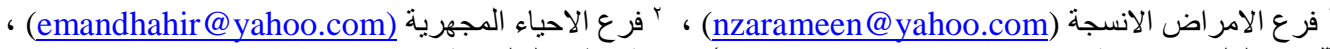

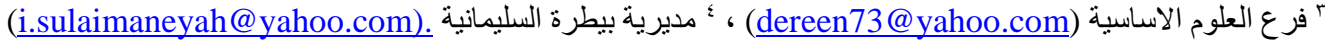

E-mail: $\underline{\text { nzarameen@yahoo.com Assiut University web-site: www.aun.edu.eg }}$

بسبب الكلفه القليلة للمضادات الحيوية وتوفره بشكل واسع تستخدم بشكل كبير في قاعات تربية الدواجن في محافظة السليمانية بشكل

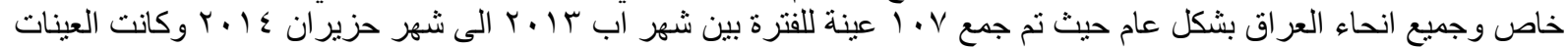

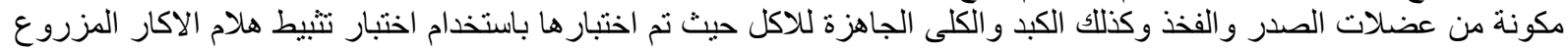

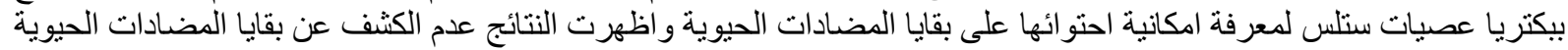

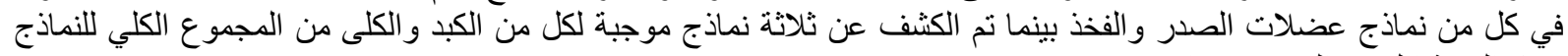

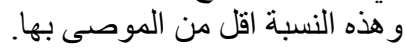

